\title{
Improvement of Quantum Teaching Model Assisted by Comics against Student Learning Outcomes
}

\author{
Marnoko $^{1}$, Sriadhi $^{2}$, M. Martiano ${ }^{3}$ \\ \{marnoko1964@gmail.com ${ }^{1}$, sriadhisy@gmail.com², martinno84@gmail.com³ \\ Universitas Muhammadiyah Sumatera Utara, Pendidikan Akuntansi ${ }^{1}$,Universitas Negeri Medan, \\ Pendidikan Teknologi Informatika dan Komputer ${ }^{2,3}$
}

\begin{abstract}
Research focus on the low student learning outcomes 6th semester advanced accounting courses II in the accounting study program at the University of Muhammadiyah North Sumatra 2017/2018 Learning Year. The purpose of this study was to determine the effect of Quantum Teaching Type Active Learning Model aided by Comic Media on Improving Student Learning Outcomes. The population of 6th semester is 144 students. The results showed that 1) Through the cooperative quantum Cooperative learning model showed a very effective increase in student learning activities namely the average score of student learning outcomes in the first cycle of 66.55, in the second cycle increased with the average activity of students in the second cycle achieving 70.22., in the Third cycle increased with an average of student activity in the third cycle reached 73.30, and in the Fourth cycle increased with an average student activity in the fourth cycle reaching 73.30 , Thus it can be concluded that, there is a significant effect of the Active Learning Model Type Quantum Teaching assisted by Comic Media Against the Improvement of Results in Advanced Accounting Learning II.
\end{abstract}

Keywords: accounting, media, outcomes, cycle

\section{Introduction}

The use of media for learning really supports student learning outcomes because of the role of the media it is very important to avoid the assumptions of students, observations at the University of Muhammadiyah North Sumatra in advanced accounting courses II semester 6, the use of media as learning still has not played an active role, the media which is generally used, namely the use of projector as teaching material, this causes it to be one-way, so that students obtain student learning outcomes as follows: 


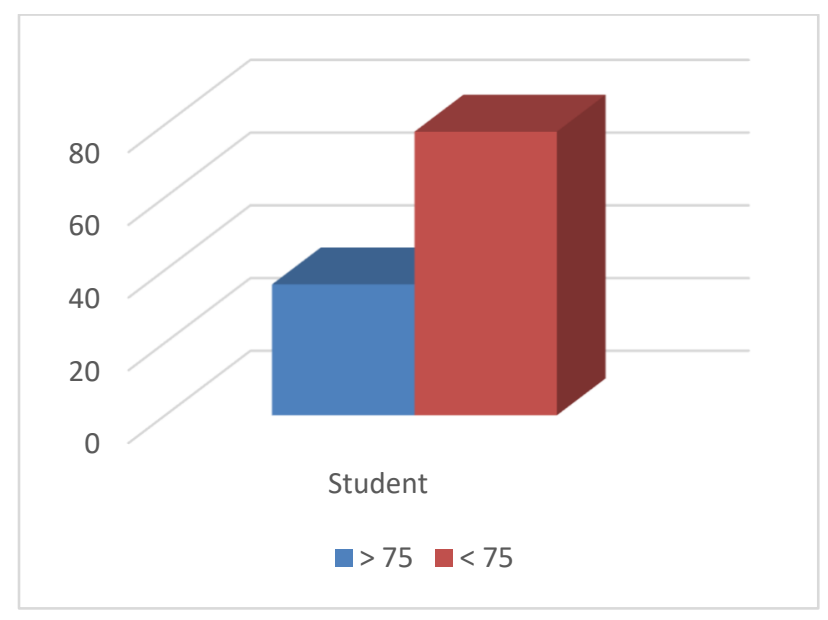

Fig. 1. Student Learning Outcomes

Based on the above data students have a score below 75 as many as 78 people while students who score above 75 are 36 . It can be concluded that new methods are needed to attract students to be able to play an active role in lectures one of them by using the quantum teaching comic model. Quantum teaching can create quality interactions that can improve learning outcomes while comics can make students better understand the lesson because comics can make learning more fun. Quantum Teaching describes new ways that facilitate the learning process so that it is easy to analyze problems and achieve their goals, especially in the discussion of adjusting journal material in service companies. The material tends to require understanding and accuracy, so by using the Quantum Teaching Model assisted by Comic Media, it is expected that students will be able to find their own solutions to problems in adjusting service company journals.

\section{Research Methods}

The purpose of this research is to see an increase in student learning activities, and how lecturers prepare, and master the material using the Quantum Teaching model assisted by Comic Media. The design of this research model has 4 cycles namely planning, implementation, action, observation and reflection. The intended planning the Quantum Teaching model assisted by Comic Media, in advanced financial accounting courses II, Creating Lecture Program Units (SAP) in accordance with the model used, making student worksheets, designing and determining the implementation of the Quantum Teaching model assisted by Comic Media, preparing tools and materials to assist the research process, creating an observation letter format between lecturers and students, measuring students the range of values used for the description test in this study is 0 to 100 with the formula:

$$
X_{i}=\frac{S p i}{S m} x 100
$$


With:

$\mathrm{Xi}=$ Value obtained by the $\mathrm{i}$-th student

$\mathrm{Spi}=$ Score obtained by the $\mathrm{i}$-th student

$\mathrm{Sm}=$ Maximum score possible (ideal score)

Calculate the average value of student learning outcomes with the formula:

$$
\bar{X}=\frac{\sum_{i=1}^{n} \bar{X}_{i}}{N}
$$

$\bar{X}=$ average value obtained by students

$\mathrm{Xi}=$ The total number of scores obtained by students overall

$\mathrm{n}=$ the total number of students

Determine the level of mastery learning achievement in a classical percentage of the number of students whose learning outcomes are complete, using the formula:

$$
\frac{\sum T B}{N} X 100 \%
$$

With:

$\sum T B=$ Number of students who have completed their studies

$N=$ Total number of students

\section{Results and Discussion}

Research Results Observation of Student Learning Activities Comic quantum learning models on advanced accounting material were obtained using observation sheets of student learning activities. To determine the achievement of the indicators in the student activity observation sheet given a score of accomplishment for each activity carried out by students during the learning process that starts with a Score of 1 to 4 . 


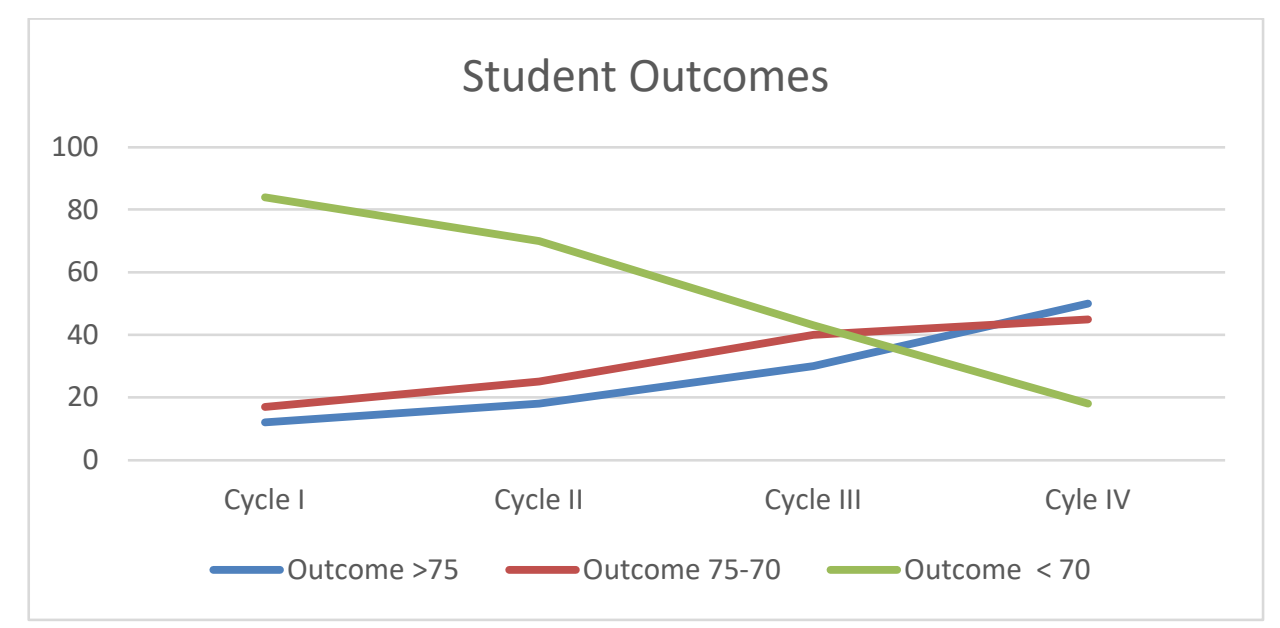

Fig. 2. Student Learning Outcomes Every Cycle

From the results of observations of the activities of students in the first cycle showed the total number of scores obtained by 84 students with an average student activity reaching a value of $<75,17$ students getting a score of $70-75$, and 12 students getting grades above 75 . based on observations made by lecturers, students still do not read the habit because comics are still dominated by a large amount of writing, and also lecturers' explanations of the material are not well understood by students, and students are embarrassed to ask about the material presented. To overcome this, the researcher made an innovation adding questions that were carried out by the comic, so students had to solve the cases given by the comic. The results obtained in cycle II are 70 students who have grades below 70, student learning outcomes in 70-75 namely 25 people, and 18 students get grades $>75$. Based on observations students begin to actively work on assignments given by comics and students ask the lecturer about the material provided. This study was continued in cycle III, the results obtained were 43 students achieving grades below 70 , there were 40 students achieving grades 75-70, and 30 students achieving grades above 70, on this last cycle originating from the student's broad value obtained 18 students had grades below 70, 45 students have grades 75-70, and 50 students have grades $>75$. So that it can be seen the development of average scores obtained by students: 


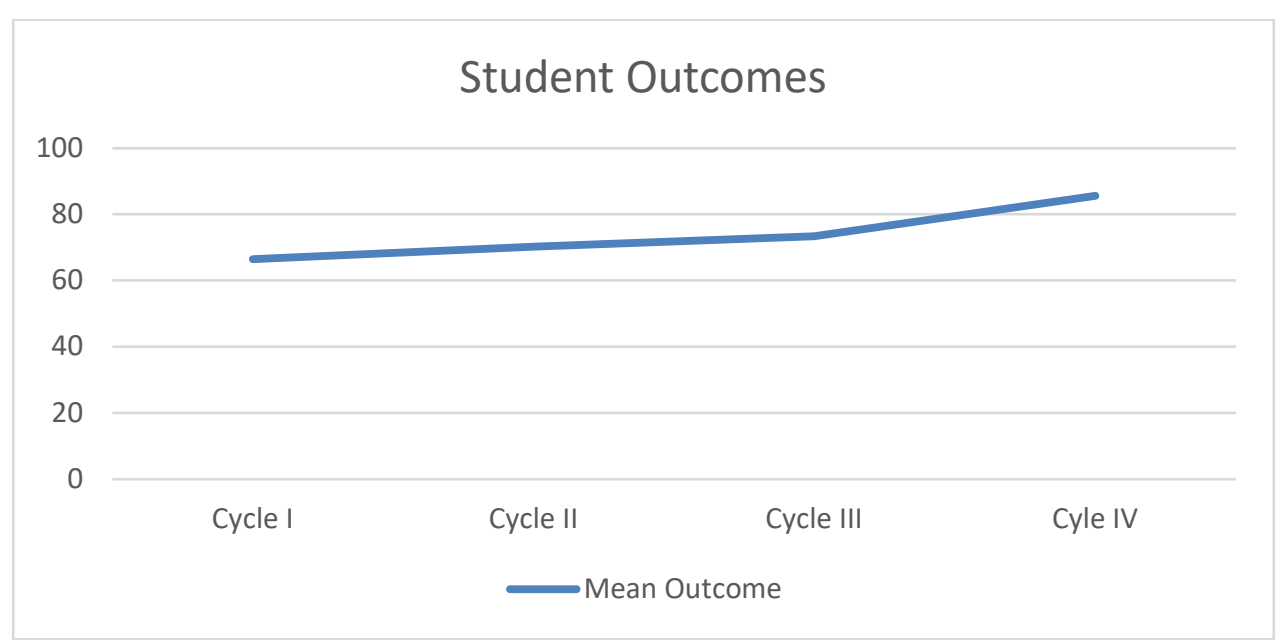

Fig. 3. Student Learning Outcomes Every Cycle

From the picture can be seen that in the first cycle the average value of students reached 66.55 , in the second cycle the average value of students reached 70.22 , in the third cycle reached 73.30, and in the fourth cycle it reached 85.66.

\section{Conclusion}

After applying the comic quantum learning model showed a very effective increase in student learning activities namely the average score of student activities in the first cycle 66.55 then in the second cycle experienced a significant increase in the average student activity in the second cycle reached 70.22, the implementation of student learning activities the comic quantum model has a positive impact on student learning outcomes. This is because the number of learning outcomes below $<70$ is reduced from the first cycle which is 84 students, in the second cycle that is 70 students, in the third cycle that is 43 students, and in the fourth cycle that is 18 students.

\section{Reference}

[1] Akbar, S, M. Pengaruh Model Quantum Teaching terhadap Motivasi Siswa Pada Standar Kompetensi Dasar-Dasar Elektronika di SMK NU SUNAN DRAJAT PACIRAN LAMONGAN. Jurnal Pendidikan Teknik Elektro Dipublikasi, Fakultas Teknik Elektro Universitas Negeri Surabaya (2014).

[2] Anas, Sudijono. Pengantar Evaluasi Pendidikan. Jakarta: Raja Grafindo Persada (2009).

[3] Andrey ,H ,Ahmad, B,H, Luciana,H. Akuntansi Keuangan Dasar Berbasis PSAK. Jakarta : Mitra Wacana Media (2013).

[4] Arsyad, A. Media Pembelajaran. ${ }^{\text {st }}$ Edition. Jakarta: Rajawali Pers (2011). 
[5] Aunurrahman. Belajar dan Pembelajaran. Bandung: Alfabeta (2012).

[6] Daryanto. Media Pembelajaran. Yogyakarta: Gava Media (2011).

[7] Dewi, C, E. Pengembangan Komik Akuntansi sebagai Media Pembelajaran Akuntansi Pada Materi Jurnal Penyesuaian untuk Siswa Kelas XI IPS SMA Negeri 1 IMOGIRI Tahun Ajaran 2015/2016. Published Thesis, Program Studi Akuntansi Fakultas Ekonomi Universitas Negeri Yogyakarta (2016).

[8] Hartini, D. Modul Akuntansi 1B. Jakarta : Erlangga (2008).

[9] Nitami, D. Pengaruh Model Pembelajaran Quantum Teaching dengan Pendekatan Scientific Terhadap Hasil Belajar Akuntansi Siswa Kelas X AK di Smk Negeri 1 Tanjung Pura Tahun Ajaran 2016/2017. Unpublished Thesis, Fakultas Ekonomi Universitas Negeri Medan (2017).

[10] Rahmaniar, A, Soegijanto. Pengantar Akuntansi Dasar 1. Bogor : In Media (2016).

[11] Rusman. Seri Manajemen Sekolah Bermutu Model-Model Pembelajaran Mengembangkan Profesionalisme Guru. Jakarta: Raja Grafindo Persada (2013).

[12] Shoimin, A. 68 Model Pembelajaran Inovatif dalam Kurikulum 2013. Yogyakarta: ArRuzz Media (2016).

[13] Sudjana, Nana, Ahmad Rivai. Media Pengajaran. Bandung: Sinar Baru Algesindo (2011).

[14] Sugiono. Metode Penelitian Pendidikan Pendekatan Kuantitatif,Kualitatif dan R\&D. Bandung : Alfabeta (2016).

[15] Susilana, R dan Riyana, C. Media Pembelajaran Hakikat, Pengembangan.Pemanfaatan dan Penilaian. Bandung: Wacana Prima (2009). 